\title{
Aflatoxin B1 in the Iranian pistachio nut and decontamination methods: A systematic review
}

\author{
Mohsen Mokhtarian ${ }^{1}$,Hamid Tavakolipour ${ }^{2}$, Foroud Bagheri ${ }^{3}$, Carlos Augusto Fernandes Oliveira ${ }^{4}$, Carlos \\ Humberto Corassin ${ }^{4}$, Amin Mousavi Khaneghah ${ }^{5, *}$ \\ ${ }^{1}$ Department of Food Science and Technology, Roudehen Branch, Islamic Azad University, Roudehen, Iran; \\ ${ }^{2}$ Department of Food Science and Technology, Sabzevar Branch, Islamic Azad University, Sabzevar, Iran; \\ ${ }^{3}$ Department of Food Science and Technology, Yasooj Branch, Islamic Azad University, Yasooj, Iran; ${ }^{4}$ Department \\ of Food Engineering, School of Animal Science and Food Engineering, University of São Paulo, São Paulo, Brazil; \\ ${ }^{5}$ Department of Food Science, Faculty of Food Engineering, University of Campinas (UNICAMP), São Paulo, Brazil
}

*Corresponding Authors: Mohsen Mokhtarian, Ph.D., Department of Food Science and Technology, Roudehen Branch, Islamic Azad University, Roudhen, Iran Email: mokhtarian.mo@riau.ac.ir; Amin Mousavi Khaneghah, Ph.D., Department of Food Science, Faculty of Food Engineering, University of Campinas (UNICAMP), Rua Monteiro Lobato, 80. Caixa Postal: 6121.CEP: 13083-862, Campinas, São Paulo, Brazil. Email: mousavi@unicamp.br

Received: 3 July 2020; Accepted: 22 September 2020; Published: 07 October 2020

(C) 2020 Codon Publications

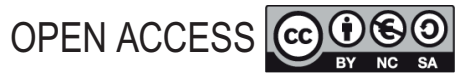

REVIEW ARTICLE

\begin{abstract}
This study aimed to summarize the occurrence of aflatoxin $B_{1}\left(A_{F B}\right)$ in the various cultivars of the Persian pistachio nut and the decontamination techniques, with the aid of a systematic review and meta-analysis. In this regard, all published studies up to November 2019 among international and national databases were screened, resulting in 23 articles. According to the findings, the main aflatoxin identified in the pistachio nut was $\mathrm{AFB}_{1}$, with $\mathrm{AFB}_{1}$ concentrations in $\sim 28 \%$ of the studies being $\leq 5 \mu \mathrm{g} / \mathrm{kg}$, in $\sim 35 \%$ of the studies being $\leq 10 \mu \mathrm{g} / \mathrm{kg}$, and in $\sim 37 \%$ of the studies being $\geq 10 \mu \mathrm{g} / \mathrm{kg}$. Generally, in most studies $(\sim 72 \%)$, AFB ${ }_{1}$ content in pistachio cultivars was higher than the acceptable level proposed by the Iranian National Standard. Although several physical and chemical techniques for $\mathrm{AFB}_{1}$ reduction have been introduced, most of them are not safe and/or suitable for human consumption.
\end{abstract}

Keywords: Pistachio nut; aflatoxin $\mathrm{B}_{1 ;}$ prevalence; systematic review; decontamination

\section{Introduction}

Pistachio (Pistacia vera L.), an important plant of the Anacardiaceae family, is one of the main Iranian agricultural products (Kola et al., 2018; Mokhtarian et al., 2017; Tavakolipour and Mokhtarian, 2014; Tavakolipour et al., 2017). In 2016, the United States, Iran, and Turkey were the leading pistachio producers globally, reaching $1,335,480,1,034,999$, and 558,303 metric tons, respectively (FAO, 2016). The pistachio nut is consumed in several countries, either as a snack or as an ingredient in food preparation (kernel or powder). A rich composition, including $25 \%$ protein (usually essential amino acids),
$10 \%$ dietary fiber, $55 \%$ oil ( $~ 80 \%$ unsaturated fatty acids), and $16 \%$ carbohydrates, provides a high nutritional value for many pistachio-based, traditional Iranian deserts, including Baghlava, Gaz and Ghotab (Mokhtarian et al., 2016; Tavakolipour and Mokhtarian, 2016; Tavakolipour et al., 2017). Although pistachio plays an essential role as a major food item in Iran, more than half of the annual Iranian production is exported, thus requiring appropriate production systems for the exported nuts' quality assurance.

Aspergillus parasiticus, A. nomius, and A. flavus are important toxigenic fungi that can infect various nuts, 
such as pistachio, and contaminate them with aflatoxin $G_{1}\left(\mathrm{AFG}_{1}\right), \mathrm{B}_{1}\left(\mathrm{AFB}_{1}\right), \mathrm{G}_{2}\left(\mathrm{AFG}_{2}\right)$, and $\mathrm{B}_{2}\left(\mathrm{AFB}_{2}\right)$ (Abdallah et al., 2020; Aydin and Ulvi, 2019; Ehrlich et al., 2007). $\mathrm{AFB}_{1}$ is a genotoxic carcinogen (Hussein and Brasel, 2001), which leads to toxic effects on the kidney, liver, hematopoietic stem cells, immune system, and the fetal and reproductive systems (Heshmati et al., 2017; Khaneghah et al., 2018, 2019; Nabizadeh et al., 2018). In this regard, the Iranian Scientific Committee for Food (SCF) has reported that $\mathrm{AFB}_{1}$ is a major factor in cancer, especially for the liver, even at very low amounts (Bensassi et al., 2010). According to Iran's national standard, the maximum tolerated levels for $\mathrm{AFB}_{1}$ and the total aflatoxin (TAFT) in pistachio are 5 and $15 \mu \mathrm{g} / \mathrm{kg}$, respectively (ISIRI, 2002). However, the European Commission standardized the aflatoxin (AFT) content of pistachio as $<10 \mu \mathrm{g} / \mathrm{kg}$ (European Commission, 2010). The prevalence of AFT in the pistachio nuts has been reported previously. In 2015, the Rapid Alert System for Food and Feed (RASFF) reported a total of 475 alerts for mycotoxins, of which $89 \%$ were associated with AFT, mostly from nuts (81\%), mainly pistachio nuts, pumpkin seeds, and dried mix nuts (Pigłowski, 2019; RASFF, 2016). Georgiadou et al. (2012) investigated the AFT contamination in the pistachio nuts. In order to determine the rate of AFT contamination in the pistachio nuts, four orchards were chosen, and 20 samples (total of 80 samples) were selected from each orchard. It should be noted that AFT control of food commodities requires well-developed analytical methods (Mousavi Khaneghah et al., 2018). The combination and structure of food products, identification, and mycotoxins detection is a challenge (Campagnollo et al., 2016; Heshmati et al., 2017). Therefore, analytical methods for precise quantification of mycotoxins in the pistachio nuts have been developed, aiming to provide high sensitivity, easy-to-operate steps, rapidness, and low-cost sample preparation procedures (Rahmani et al., 2018).

In recent years, several technological approaches have been introduced to reduce the growth of fungi or for the removal of AFT from pistachios, including the application of extracts and essential oils from medicinal plants (Ijabadeniyi et al., 2020; Khorasani et al., 2017); ozone treatment $\left(\mathrm{O}_{3}\right)$ (Chen et al., 2014); the use of chemical compounds, such as methyl bromide $\left(\mathrm{CH}_{3} \mathrm{Br}\right)$, hydrogen peroxide $\left(\mathrm{H}_{2} \mathrm{O}_{2}\right)$, sodium bisulfite $\left(\mathrm{NaHSO}_{3}\right)$, and ammonia; the use of adsorbent compounds, such as active charcoal, zeolite, sodium bentonite, hydrated sodium calcium aluminosilicate (HSCAS); gamma radiation (Serra et al., 2018); and biological methods, such as mannan compounds from the cell wall of Saccharomyces cerevisiae and lactic acid bacteria (Abdallah et al., 2018; Abdolshahi et al., 2018). Examples of the application of biological methods include the report by Abdolshahi et al. (2018), who studied the interacting capacity of $S$. cerevisiae mannoprotein (mannan) with AFT in pistachio by soaking the kernels in mannan solutions at 25 and $50 \mathrm{mg} / \mathrm{mL}$. Siahmoshteh et al. (2017) investigated the efficacy of B. amyloliquefaciens and B. subtilis in controlling AFT production and Aspergillus parasiticus growth. The authors considered the Bacillus species as good biocontrol agents to reduce toxigenic fungal material growth and the subsequent AFT decontamination of pistachio. Rastegar et al. (2017) investigated the removal of $A_{F} B_{1}$ by roasting contaminated pistachio nuts mixed with lemon juice and/or citric acid.

It can be stated that, due to the economic, nutritional, and health aspects of the Iranian pistachio nut (Mokhtarian, 2015; Ros, 2010), along with the high susceptibility of this product to fungal growth (especially to Aspergillus spices), there is a need for strategies to reduce AFT contamination at different stages of harvest, postharvest, and during the processing of this product. Therefore, this study aimed to review the data from all available studies on the prevalence of $\mathrm{AFB}_{1}$ in different Iranian pistachio cultivars and recommend effective ways to combat this severe challenge.

\section{Search Strategy}

\section{Keywords and screened databases}

In order to study the prevalence of $\mathrm{AFB}_{1}$ in the different Iranian pistachio cultivars, all published studies up to December of 2018 were screened using "Scopus," "PubMed," and "SID" databases using the keywords, "Pistachio nut," "Pistachio kernel," "Aflatoxin contamination," "Aspergillus flavus," "Anti-aflatoxigenic," "Anti-mycotoxigenic," "Iranian," and "Persian." Also, all references in the retrieved studies were reviewed to prevent any study from being missed out. It should be noted that all studies that examined the analytical methods of AFT detection in pistachios were excluded from the research.

\section{Data extraction}

Considering that the pistachio is one of Iran's nonoil and strategic products, in this study, only the research carried out by Iranian researchers was addressed. From each study, the required information, including author name (researcher), publication year, analytical technique, pistachio cultivar, an average of the reported $\mathrm{AFB}_{1}$, number of samples, the ratio of the measured AFT to the maximum tolerated level of $\mathrm{AFB}_{1}$ following the Iranian national standard $\mathrm{AFB}_{1 \mathrm{R}} / \mathrm{AFB}_{1 \mathrm{~S}}$, and the method applied to reduce AFTs in pistachio were obtained. 


\section{Main Findings}

\section{Study characteristics}

In the initial evaluation of the 1582 articles collected, 674 were excluded because of duplication (repeated articles) and irrelevant data descriptions. A total of 908 articles extracted as the primary articles based on abstracts and titles were excluded because 835 articles reported on other toxins and 73 articles did not describe the analytical method used. Only those researches reporting the AFT contamination with the particular analytical method used and studies on decontamination techniques in pistachio nuts were evaluated. At the end of the data extraction procedure, 23 articles published before 30 December 2018 were selected and evaluated in our study (Tables 1,2, and Figure 1).

Table 1. Published researches related to the prevalence of $A F B_{1}$ contamination in the pistachio nuts produced in Iran.

\begin{tabular}{|c|c|c|c|c|c|}
\hline Pistachio cultivar & $\begin{array}{l}\text { Average of } \text { AFB }_{1} \\
\text { reported in research } \\
(\mu \mathrm{g} / \mathrm{kg})\end{array}$ & $\begin{array}{l}\text { Number of } \\
\text { studied } \\
\text { samples (N) }\end{array}$ & Ratio $\frac{\mathrm{AFB}_{1 \mathrm{R}}{ }^{* *}}{\mathrm{AFB}_{1 \mathrm{~S}}{ }^{* *}}$ & $\begin{array}{l}\text { Identification } \\
\text { method }\end{array}$ & Ref. \\
\hline \multirow[t]{2}{*}{ O'hadi } & 285.5 & 10 & $\sim 57$ & HPLC & Mehrnezhad and Panahi, 2005 \\
\hline & 1485 & 14 & $\sim 297$ & & \\
\hline O'hadi & 6.25 & - & 1.25 & TLC & Pak-kish and Rahemi, 2005 \\
\hline Akbari & 10 & - & 2 & HPLC & Rahaie et al., 2010b \\
\hline Akbari & 5.63 & - & 1.126 & HPLC & Tavakolipour et al., 2012 \\
\hline Fandoghi (Early split) & - & 7.93 & $\sim 1.59$ & ELISA & Dargahi et al., 2014 \\
\hline Fandoghi (Whole) & 1.59 & - & $\sim 0.32$ & ELISA & Dargahi et al., 2014 \\
\hline Unknown & $\sim 0.681$ & 72 & $\sim 0.136$ & HPLC & Shakeri and Fazaeli, 2016 \\
\hline Kermani & 5.9 & 3356 & 1.18 & HPLC & Cheraghali et al., 2007 \\
\hline Unknown & 8.12 & - & $\sim 1.63$ & HPLC & Aghamohammadi et al., 2007 \\
\hline Kermani & $\sim 311.6$ & 3181 & $\sim 62.32$ & HPLC & Dini et al., 2013 \\
\hline Ahmad Aghaei (Damghan) & 2.077 & 600 & $\sim 0.42$ & HPLC & Taghizadeh et al., 2018 \\
\hline Akbari (Damghan) & 1.948 & 600 & 0.3896 & & \\
\hline Kalle-Ghuchi (Damghan) & 1.627 & 600 & 0.3254 & & \\
\hline O'hadi (Damghan) & $<0.066$ & 600 & 0.0132 & & \\
\hline Badami (Damghan) & $<0.066$ & 600 & 0.0132 & & \\
\hline Ahmad Aghaei (Feyz Abad) & 3.863 & 600 & 0.7726 & & \\
\hline Akbari (Feyz Abad) & 3.081 & 600 & 0.6162 & & \\
\hline Kalle-Ghuchi (Feyz Abad) & 2.143 & 600 & 0.4286 & & \\
\hline O'hadi (Feyz Abad) & 0.2 & 600 & 0.04 & & \\
\hline Badami (Feyz Abad) & 0.2 & 600 & 0.04 & & \\
\hline Ahmad Aghaei (Rafsanjan) & 4.33 & 600 & 0.866 & & \\
\hline Akbari (Rafsanjan) & 4.08 & 600 & 0.816 & & \\
\hline Kalle-Ghuchi (Rafsanjan) & 3.453 & 600 & 0.6906 & & \\
\hline O'hadi (Rafsanjan) & 0.2 & 600 & 0.04 & & \\
\hline Badami (Rafsanjan) & 0.2 & 600 & 0.04 & & \\
\hline Ahmad Aghaei (Sarakhs) & 0.961 & 600 & 0.1922 & & \\
\hline Akbari (Sarakhs) & 0.487 & 600 & 0.0974 & & \\
\hline Kalle-Ghuchi (Sarakhs) & 0.233 & 600 & 0.0466 & & \\
\hline O'hadi (Sarakhs) & $<0.066$ & 600 & 0.0132 & & \\
\hline Badami (Sarakhs) & $<0.066$ & 600 & 0.0132 & & \\
\hline Unknown & $22.02^{\star \star \star \star}$ & 43 & $\sim 4.4$ & ELISA & Ostadrahimi et al., 2014 \\
\hline \multicolumn{6}{|c|}{$\begin{array}{l}\text { *Maximum tolerated level of AFB1 in accordance with the Iranian National Standard (No. 5925, } \\
{ }^{* *} \text { AFB1R: Obtained AFB1 content in accordance with the research. } \\
{ }^{* * *} \text { AFB1S: The AFB1 content in accordance with the Iranian National Standard (1380). } \\
\text { ****In this research, the noted value is for TAFT. }\end{array}$} \\
\hline
\end{tabular}


Table 2. The published applied researches related to the decontamination methods of $A F B_{1}$ in the pistachio nuts produced in Iran.

\begin{tabular}{|c|c|c|c|c|c|}
\hline \multirow[t]{2}{*}{ Pistachio cultivar } & \multicolumn{2}{|c|}{ Average of AFB1 $(\mu \mathrm{g} / \mathrm{kg})$} & \multirow[t]{2}{*}{ Aflatoxin decontamination method } & \multirow{2}{*}{$\begin{array}{l}\text { Amount } \\
\text { of toxin } \\
\text { removal }(\%)\end{array}$} & \multirow[t]{2}{*}{ Ref. } \\
\hline & $\begin{array}{l}\text { Before } \\
\text { treatment }\end{array}$ & $\begin{array}{c}\text { After } \\
\text { treatment }\end{array}$ & & & \\
\hline O'hadi & 6.25 & 1.2 & $25 \mathrm{mg} / \mathrm{l}$ Gibberellic acid & $\sim 81$ & Pak-kish and Rahemi, 2005 \\
\hline Ahmad Aghaei & $\sim 2.75$ & $\sim 0.5$ & Phenolics of pistachio green hull & $\sim 81$ & Afshari et al., 2009 \\
\hline Akbari & 10 & 6 & $\begin{array}{l}\text { Inoculation of pistachio by } \\
\text { Saccharomyces cerevisiae yeast }\end{array}$ & 40 & Rahaie et al., 2010a \\
\hline Akbari & 16.467 & 5.644 & Extract of Shirazi thyme & $\sim 66$ & Tavakolipour et al., 2010 \\
\hline Shahpasand & 32,300 & 31,171 & Testa (Pistachio kernel coat) & $\sim 3.49$ & Mohammadi Moghadam et al., \\
\hline Abasali & 32,307 & 30,754 & & $\sim 4.81$ & 2011 \\
\hline O'hadi & 32,810 & 29,823 & & $\sim 9.11$ & \\
\hline Ahmad Aghaei & 30,171 & 29,429 & & $\sim 2.46$ & \\
\hline Akbari & 29,940 & 26,880 & & $\sim 10.22$ & \\
\hline Kale-Bozi & 27,439 & 26,410 & & $\sim 3.75$ & \\
\hline Kalle-Ghuchi & 30,433 & 26,218 & & $\sim 13.85$ & \\
\hline FAS-13-73 & 29,012 & 25,393 & & $\sim 12.47$ & \\
\hline Fakhri & 30,762 & 24,811 & & $\sim 19.35$ & \\
\hline Kal-e-Khandan & 27,912 & 21,728 & & $\sim 22.15$ & \\
\hline Akbari & 16.467 & 5.644 & Extract of the Shirazi thyme & $\sim 66$ & Tavakolipour et al., 2012 \\
\hline \multirow[t]{4}{*}{ Unknown } & 1700.63 & 610.32 & $\begin{array}{l}\text { Trichoderma spp. } T_{1} \text { extracellular } \\
\text { extract }\end{array}$ & $\sim 64.11$ & Chegini, Behbodi et al., 2013 \\
\hline & & 265.29 & $\begin{array}{l}\text { Trichoderma spp. } T_{3} \text { extracellular } \\
\text { extract }\end{array}$ & $\sim 84.4$ & \\
\hline & & 376.03 & $\begin{array}{l}\text { Trichoderma spp. } T_{4} \text { extracellular } \\
\text { extract }\end{array}$ & $\sim 77.88$ & \\
\hline & & 825.75 & $\begin{array}{l}\text { Trichoderma spp. } \mathrm{T}_{17} \text { extracellular } \\
\text { extract }\end{array}$ & $\sim 51.44$ & \\
\hline \multirow[t]{2}{*}{ O'hadi } & - & - & 4 ppm soluble ozone in water & 32.7 & Bashiri et al., 2013 \\
\hline & - & - & $8 \mathrm{ppm}$ soluble ozone in water & 47.9 & \\
\hline \multirow[t]{4}{*}{ Unknown } & - & - & Radiation at $1 \mathrm{kGy}$ & 38.84 & Haji Mohammadi et al., 2016 \\
\hline & - & & Radiation at 3 kGy & 48.79 & \\
\hline & - & & Radiation at $5 \mathrm{kGy}$ & 53.50 & \\
\hline & - & & Radiation at $7 \mathrm{kGy}$ & 77.17 & \\
\hline \multirow{3}{*}{$\begin{array}{l}\text { Unknown (Pistachio } \\
\text { kernel) }\end{array}$} & 44 & & Roasted at $150^{\circ} \mathrm{C}(30 \mathrm{~min})$ & 66 & Yazdanpanah et al., 2005 \\
\hline & 91 & & & 64 & \\
\hline & 213 & - & & 24 & \\
\hline \multirow{2}{*}{$\begin{array}{l}\text { Unknown (Whole } \\
\text { pistachio) }\end{array}$} & 144 & - & Roasted at $150^{\circ} \mathrm{C}(30 \mathrm{~min})$ & 63 & \\
\hline & 253 & - & & 19 & \\
\hline Unknown & $\sim 2500$ & $\sim 450$ & $\begin{array}{l}\text { Inoculation of pistachio by Bacillus } \\
\text { subtilis (UTBSP1) for } 96 \mathrm{~h} \text { at } 30^{\circ} \mathrm{C}\end{array}$ & 82 & Farzaneh et al., 2012 \\
\hline \multirow[t]{4}{*}{ Ahmad Aghaei } & - & - & $\begin{array}{l}\text { Inoculation of pistachio by Bacillus } \\
\text { amyloliquefaciens (UTBSP1) for } \\
5 \text { days at } 30^{\circ} \mathrm{C}\end{array}$ & 23.9 & Siahmoshteh et al., 2017 \\
\hline & - & & $\begin{array}{l}\text { Inoculation of pistachio by Bacillus } \\
\text { amyloliquefaciens (UTBSP1) for } \\
8 \text { days at } 30^{\circ} \mathrm{C}\end{array}$ & 54.9 & \\
\hline & - & & $\begin{array}{l}\text { Inoculation of pistachio by Bacillus } \\
\text { subtilis for } 5 \text { days at } 30^{\circ} \mathrm{C}\end{array}$ & 41.1 & \\
\hline & - & & $\begin{array}{l}\text { Inoculation of pistachio by Bacillus } \\
\text { subtilis for } 8 \text { days at } 30^{\circ} \mathrm{C}\end{array}$ & 52.5 & \\
\hline
\end{tabular}


Table 2. Continued

\begin{tabular}{|c|c|c|c|c|c|}
\hline \multirow[t]{2}{*}{ Pistachio cultivar } & \multicolumn{2}{|c|}{ Average of AFB1 $(\mu \mathrm{g} / \mathrm{kg})$} & \multirow[t]{2}{*}{ Aflatoxin decontamination method } & \multirow{2}{*}{$\begin{array}{l}\text { Amount } \\
\text { of toxin } \\
\text { removal (\%) }\end{array}$} & \multirow[t]{2}{*}{ Ref. } \\
\hline & $\begin{array}{l}\text { Before } \\
\text { treatment }\end{array}$ & $\begin{array}{c}\text { After } \\
\text { treatment }\end{array}$ & & & \\
\hline \multirow[t]{2}{*}{ Unknown } & 268 & - & $\begin{array}{l}\text { Roasting of pistachio at } 120^{\circ} \mathrm{C} \text { for } 60 \\
\text { min by incorporation of } 30 \mathrm{~mL} \text { distilled } \\
\text { water, } 15 \mathrm{~mL} \text { lemon juice, } 2.25 \mathrm{~g} \text { citric } \\
\text { acid, and } 5 \mathrm{~g} \mathrm{NaCl}\end{array}$ & 58.6 & Rastegar et al., 2017 \\
\hline & 268 & - & $\begin{array}{l}\text { Roasting of pistachio at } 150^{\circ} \mathrm{C} \text { for } 60 \\
\text { min by incorporation of } 30 \mathrm{~mL} \text { distilled } \\
\text { water, } 15 \mathrm{~mL} \text { lemon juice, } 2.25 \mathrm{~g} \text { citric } \\
\text { acid, and } 5 \mathrm{~g} \mathrm{NaCl}\end{array}$ & 47 & \\
\hline \multirow[t]{2}{*}{ Unknown } & - & - & $\begin{array}{l}\text { Soaking of pistachio in mannan } \\
\text { solution }(25 \mathrm{mg} / \mathrm{mL})\end{array}$ & 63.4 & Abdolshahi et al., 2018 \\
\hline & - & - & $\begin{array}{l}\text { Soaking of pistachio in mannan } \\
\text { solution }(50 \mathrm{mg} / \mathrm{mL})\end{array}$ & 84.4 & \\
\hline \multirow[t]{4}{*}{ Unknown } & $\sim 2500$ & $\sim 1750$ & $\begin{array}{l}\text { Inoculation of pistachio by Bacillus } \\
\text { subtilis (UTB1) for } 72 \mathrm{~h} \text { at } 37^{\circ} \mathrm{C}\end{array}$ & 30 & Afsharmanesh et al., 2018 \\
\hline & $\sim 2500$ & $\sim 1750$ & $\begin{array}{l}\text { Inoculation of pistachio by Bacillus } \\
\text { subtilis (UTB1) and mutant } \\
\text { (B1 } \mathrm{b} \text { bacC5) for } 72 \mathrm{~h} \text { at } 37^{\circ} \mathrm{C}\end{array}$ & 30 & \\
\hline & $\sim 2500$ & $\sim 1580$ & $\begin{array}{l}\text { Inoculation of pistachio by Bacillus } \\
\text { subtilis (UTB1) and mutant } \\
\text { (B1 } \Delta \text { bacC12) for } 72 \mathrm{~h} \text { at } 37^{\circ} \mathrm{C}\end{array}$ & 36.8 & \\
\hline & $\sim 2500$ & $\sim 1000$ & $\begin{array}{l}\text { Inoculation of pistachio by Bacillus } \\
\text { subtilis (UTB1) and mutant mutant } \\
\text { (B1 } \triangle \text { bacC18) for } 72 \mathrm{~h} \text { at } 37^{\circ} \mathrm{C}\end{array}$ & 60 & \\
\hline \multirow[t]{2}{*}{ Akbari } & 10 & - & Inoculation of pistachio by & 40 & Rahaie et al., 2010a \\
\hline & 20 & - & $\begin{array}{l}\text { Saccharomyces cerevisiae yeast for } \\
12 \mathrm{~h} \text { at } 25^{\circ} \mathrm{C}\end{array}$ & 70 & \\
\hline \multirow[t]{2}{*}{ Akbari } & 10 & - & Inoculation of pistachio by & 60 & \\
\hline & 20 & - & $\begin{array}{l}\text { Saccharomyces cerevisiae yeast } \\
\text { for } 12 \mathrm{~h} \text { at } 25^{\circ} \mathrm{C} \text { along with acidic } \\
\text { treatment }(2 \mathrm{M} \mathrm{HCL})\end{array}$ & 73 & \\
\hline \multirow[t]{2}{*}{ Akbari } & 10 & - & Inoculation of pistachio by & 55 & \\
\hline & 20 & - & $\begin{array}{l}\text { Saccharomyces cerevisiae yeast for } \\
12 \mathrm{~h} \text { at } 25^{\circ} \mathrm{C} \text { along with heat treat- } \\
\text { ment (autoclave at } 121^{\circ} \mathrm{C} \text { for } 20 \mathrm{~min} \text { ) }\end{array}$ & 75 & \\
\hline \multirow[t]{5}{*}{ Akbari } & - & - & $\begin{array}{l}\text { Addition of Salicylic acid solution } \\
(1 \mathrm{mmol} / \mathrm{l}) \text { to medium culture }\end{array}$ & $\sim 30$ & Panahirad et al., 2014 \\
\hline & - & - & $\begin{array}{l}\text { Addition of Salicylic acid solution } \\
(3 \mathrm{mmol} / \mathrm{l}) \text { to medium culture }\end{array}$ & $\sim 42$ & \\
\hline & - & - & $\begin{array}{l}\text { Addition of Salicylic acid solution } \\
(5 \mathrm{mmol} / \mathrm{l}) \text { to medium culture }\end{array}$ & $\sim 50$ & \\
\hline & - & - & $\begin{array}{l}\text { Addition of Salicylic acid solution } \\
(7 \mathrm{mmol} / \mathrm{l}) \text { to medium culture }\end{array}$ & $\sim 87$ & \\
\hline & - & - & $\begin{array}{l}\text { Addition of Salicylic acid solution } \\
(9 \mathrm{mmol} / \mathrm{l}) \text { to medium culture }\end{array}$ & $\sim 100$ & \\
\hline Akbari & - & - & $\begin{array}{l}\text { Addition of Salicylic acid solution } \\
(11 \mathrm{mmol} / \mathrm{l}) \text { to medium culture }\end{array}$ & $\sim 100$ & Panahirad et al., 2014 \\
\hline Unknown & $22.02^{* *}$ & 0.48 & Roasting of pistachio with salt & $\sim 98$ & Ostadrahimi et al., 2014 \\
\hline
\end{tabular}

*Maximum tolerated level of AFB, following the Iranian National Standard (No. 5925, 1380), $5 \mu \mathrm{gg} / \mathrm{kg}$ (ISIRI, 2002).

${ }^{* *}$ In this research, the noted value is for TAFT

AFBB1, aflatoxin $B_{1}$. 


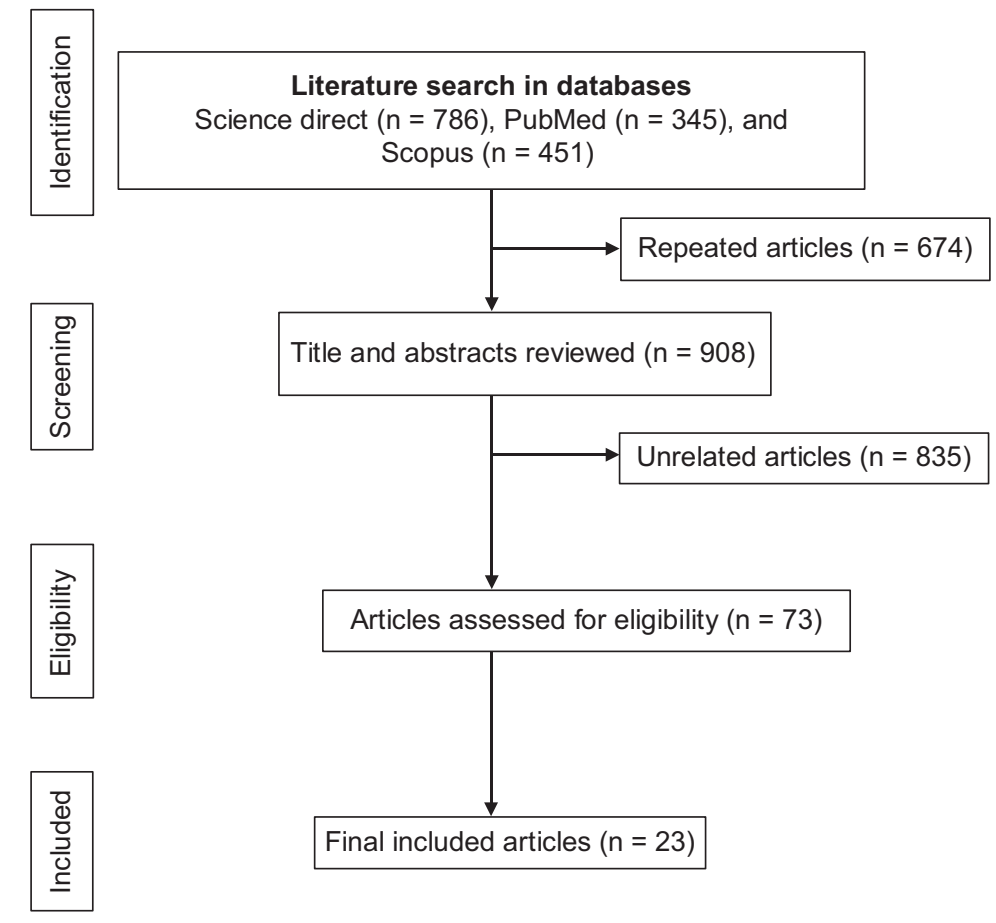

Figure 1. Flow chart of exclusion and inclusion studies based on the PRISMA guidelines.

\section{Prevalence of $\mathrm{AFB}_{1}$ in the Iranian pistachio}

According to Table 1, the evaluation and measurement of $\mathrm{AFB}_{1}$ content in the Iranian pistachio has been described in only 11 studies. Our work results indicate that the Iranian pistachio cultivars evaluated for AFT content include O'hadi, Akbari, Kermani, Ahmad Aghaei, KalleGhuchi, and Badami. Generally, the $\mathrm{AFB}_{1}$ concentrations of various Persian pistachio cultivars varied from $<0.066$ to $1,485 \mu \mathrm{g} / \mathrm{kg}$ (Table 1). The results demonstrated that, with time, the AFT content has decreased, probably because of increasing awareness among farmers concerning improving the sanitary conditions in the orchards, vehicles, and pistachio terminals. As per the results, among the published articles on the incidence of AFT in the Persian pistachio, only two studies reported $\mathrm{AFB}_{1}$ content higher than $285.5 \mu \mathrm{g} / \mathrm{kg}$, while in the other articles, the $\mathrm{AFB}_{1}$ levels varied markedly from 0.066 to $10 \mu \mathrm{g} / \mathrm{kg}\left(0.066 \leq \mathrm{AFB}_{1}\right.$ $(\mu \mathrm{g} / \mathrm{kg}) \leq 10)$. The AFT levels in $\sim 28 \%$ of the studies were lower than $5 \mu \mathrm{g} / \mathrm{kg}\left(\mathrm{AFB}_{1} \leq 5 \mu \mathrm{g} / \mathrm{kg}\right)$, while $\sim 35 \%$ of the studies reported concentrations in the range of $5 \leq \mathrm{AFB}_{1}$ $(\mu \mathrm{g} / \mathrm{kg}) \leq 10$ and $\sim 37 \%$ of the studies mentioned levels $>$ $10 \mu \mathrm{g} / \mathrm{kg}\left(\mathrm{AFB}_{1} \geq 10 \mu \mathrm{g} / \mathrm{kg}\right)$. As can be seen, the $\mathrm{AFB}_{1}$ content in a significant number of studies $(\sim 72 \%)$ was higher than the acceptable limit range set by the national standard of Iran (i.e., $<5 \mu \mathrm{g} / \mathrm{kg}$ ).

Georgiadou et al. (2012) reported that a critical point for AFT contamination of the pistachio nuts is the maturity step, ranging from 11 to $1,361 \mu \mathrm{g} / \mathrm{kg}$ among orchards. In the harvesting step, the AFT content was $>1,420 \mu \mathrm{g} / \mathrm{kg}$, and the authors concluded that the higher AFT levels $(>1000 \mu \mathrm{g} / \mathrm{kg})$ in orchards correlated with the highest insect infestations during this production step. At the postharvest level, AFT contamination in three out of four orchards varied from 650 to $1,100 \mu \mathrm{g} / \mathrm{kg}$. During the storage period, it ranged between 40 and $1,200 \mu \mathrm{g} / \mathrm{kg}$.

Considering that some environmental factors are needed to support fungal growth, such as temperature and the relative humidity of the environment and storage, proper drying and suitable storage of grains are the most important preventive actions to prevent fungal growth. In this context, fungal contamination and the subsequent AFT production in pistachio nuts may occur in orchards and farms, at harvesting time, during transportation, during the process stage, and storage, and as well as when distributing the product (Cheraghali et al., 2007).

In this study, 23 articles were found related to AFT's prevalence in the Iranian pistachio, which indicated that the most frequent AFT found in pistachio is $\mathrm{AFB}_{1}$. Several studies have confirmed the presence of $\mathrm{AFB}_{1}$ in the Iranian pistachio (Afsharmanesh et al., 2018; Panahirad et al., 2014; Rahaie et al., 2010a; Yazdanpanah et al., 2005). Dini et al. (2013) studied the AFT contamination levels in the Iranian pistachio and concluded that 
the mean $\mathrm{AFB}_{1}$ levels in this product in 2009, 2010, and 2011 were $\sim 320246$, and $\sim 370 \mu \mathrm{g} / \mathrm{kg}$, respectively. They also observed that the measured AFT was higher than those recommended by the Iranian National Standard in all the years mentioned above. In another study, Cheraghali et al. (2007) claimed that $\mathrm{AFB}_{1}$ content in $\sim 63.3 \%$ of the pistachio samples was lower than the limit of detection (LOD) of the analytical method used in the study $(5 \mu \mathrm{g} / \mathrm{kg})$.

\section{Analytical methods for the determination of AFT}

Today, the successful development of fast, robust, cheap, and simple analytical methods with high selectivity and sensitivity for measuring and identifying different mycotoxins in different foods products is a reality (Alshannaq and $\mathrm{Yu}, 2017$; Zhang et al., 2018). New methods rely on gas and high-performance liquid chromatography (HPLC) systems combined with tandem mass spectrometry (MS/ MS), thereby providing an unequivocal identification and precise quantification of multiple mycotoxins in complex food matrices (Turner et al., 2015). Also, HPLC coupled with fluorescence detection (FLD) was developed as one of the nonMS methods earlier by the European Standardization Committee (CEN) and the Association of Official Analytical Chemists (AOAC) International for the determination and identification of different mycotoxins (Kwaśniewska et al., 2015; Pascale, 2009; Pereira et al., 2014). The HPLC-FLD sensitivity is comparable to the results determined by the HPLC-MS/MS technique, but the HPLC-FLD is usually more suitable for single mycotoxin detection or the determination of mycotoxins group with similar chemical structures (Khaneghah et al., 2019). In all the literature studied (Figure 2a), the analytical methods based on HPLC were the most used for the determination of AFTs in the pistachio nuts, followed by thin-layer chromatography (TLC) and enzyme-linked immunosorbent assay (ELISA).

The ELISA method is based on the chemical interaction between a given antigen (in this case, a mycotoxin conjugated to the larger, immunogenic molecule) and its specific antibody. According to this interaction arrangement, ELISA protocols can be designed as direct, indirect, sandwich ELISA, competitive, or indirect competitive. In the
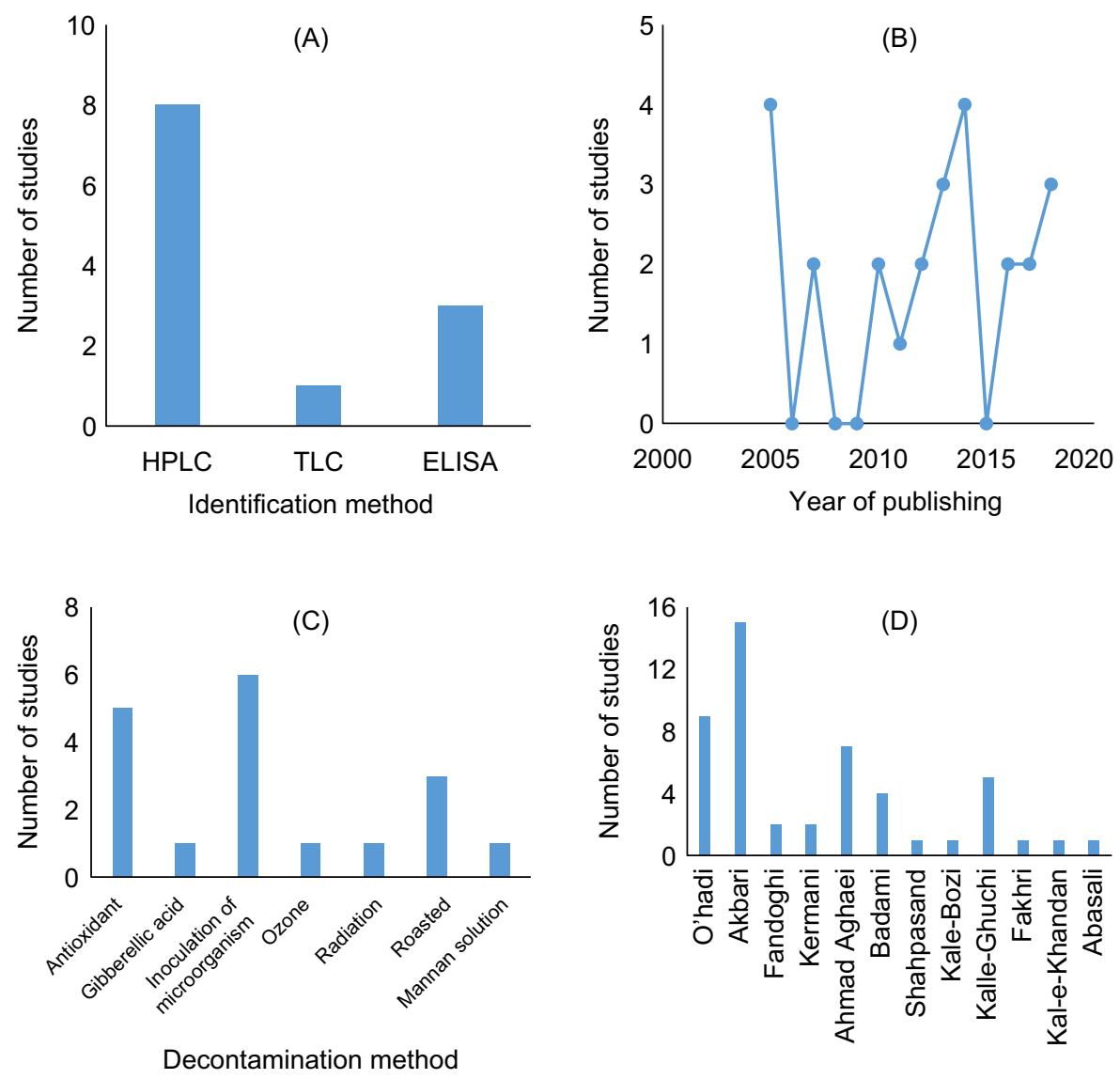

Pistachio type

Figure 2. The number of articles and studies on identification methods (A), year of publishing (D), the decontamination method (C), and the pistachio type (D). 
direct ELISA, the extract of samples reacts directly with the enzyme, thus providing rapid and beneficial results for mycotoxins' qualitative evaluation. Competitive ELISA shows the competitive reaction between sample (antibody or antigen) and target mycotoxin in the enzyme-labeled targets versus immobilized antibody or antigen. The indirect technique is based on indirectly determined target antigen using the secondary antibody, which is usually labeled as an enzyme. The indirect competitive technique's mechanism is the interaction of the primary antibody with the immobilized antigen, and in this method, a secondary antibody conjugated with an enzyme is required. In the sandwich technique, the antigen interacts with two different antibodies (Suzuki et al., 2007), which allows high specificity, rapid speed screening, simple operation without using any readers or instrument, and eco-friendly analysis due to radioactive labels and low volumes of solvents (Batrinou et al., 2020; Krska and Molinelli, 2009; Sakamoto et al., 2018).

One of the most critical limitations of the regular monitoring of mycotoxins in foods using ELISA is the high price of commercially available kits, especially in developing countries (Rossi et al., 2012). The further investments in immunoreagent manufacturing could increase the access to the kits as ELISA is the most common immunoassay applied for fast mycotoxin determination. Other fast immunoassay-based methods, including radioimmunoassay, immunoaffinity columns, and sequential injection immunoassay, have been applied to identify and determine mycotoxins in food products. Moreover, rapid, on-site test bands have been developed to measure toxic contaminants in foodstuffs, including a flow-through, lateral-flow immunoassay (LFIA), and dipstick. The lateral flow-based essay is a big, sensitive, selective, and single-step test for determining different mycotoxins in about $10 \mathrm{~min}$. This technique is based on three factors: a porous membrane, an absorbent pad, and a conjugate pad. These three factors ensure a lateral flow, increase the flowing liquid volume, and guarantee contact between the liquid sample and the membrane (Maragos and Busman, 2010).

\section{Methods for the decontamination of AFTs in the Iranian pistachio}

The experimental techniques applied for AFT decontamination of the pistachio are presented in Table 2. It is noteworthy that the majority of the studies were conducted using Iranian pistachio cultivars such as O'hadi, Ahmad Aghaei, Akbari, Shahpasand, Abasali, Kale-Bozi, KalleGhuchi, FAS-13-73, Fakhri, and Kal-e-Khandan (Table 2 , Figure $2 b$ and $d)$. In accordance to the results reported in the evaluated studies, the lowest $(2.46 \%)$ and the highest $(100 \%)$ percentages of $\mathrm{AFB}_{1}$ removal were related to treatments using "pistachio Testa (pistachio kernel coat)" and "addition of $9 \mathrm{mmol} / \mathrm{l} \mathrm{Salicylic}$ acid solution to the medium culture," respectively. Overall, the applied methods for the decontamination of AFTs in the Iranian pistachio included physical (radiation and roasting) and chemical methods (gibberellic acid, treatment with ozone, lemon extract, citric acid, salt solution, and salicylic acid solution). While biological treatments, such as Saccharomyces cerevisiae, Trichoderma extracellular extract, inoculation by Bacillus species, and recombinant mutants of Bacillus subtilis, attracted notable attention, combined methods and the use of extract and essential oils from medical plants, such as phenolic compounds from pistachio green hull, the extract of the Shirazi thyme, and Testa or the pistachio kernel coat, were also useful (Figure 2c).

Abdolshahi et al. (2018) studied the AFT-binding efficiency of S. cerevisiae mannoprotein (mannan) in contaminated pistachio nuts, observing the highest binding percentage $(84.4 \%)$ for $\mathrm{AFB}_{1}$ at a higher concentration of mannan $(50 \mathrm{mg} / \mathrm{mL})$. In another research, the simultaneous application of roasting-chemical treatment (lemon juice and citric acid) for the reduction of $\mathrm{AFB}_{1}$ in pistachio was evaluated by Rastegar et al. (2017). The authors found that roasting of pistachio nuts $(50 \mathrm{~g})$ in water $(30 \mathrm{~mL})$, lemon juice $(30 \mathrm{~mL})$, and citric acid $(6 \mathrm{~g})$ at $120^{\circ} \mathrm{C}$ for $60 \mathrm{~min}$ resulted in a significant reduction (93.1\%) of $\mathrm{AFB}_{1}$. Also, the roasting of pistachio nuts (50 g) with water $(30 \mathrm{~mL})$, lemon juice $(15 \mathrm{~mL})$, and citric acid $(2.25 \mathrm{~g})$ at $120 \mathrm{C}$ for $60 \mathrm{~min}$ decreased the level of $\mathrm{AFB}_{1}$ to $49.2 \%$ of the original content. Generally, it was reported that the simultaneous use of heat and citric acid/lemon juice had a synergistic effect on $\mathrm{AFB}_{1}$ reduction. In summary, physical, chemical, and biological methods, as proposed in several studies, could significantly reduce the pistachio nuts' AFT contents. However, methods based on the inoculation of different microorganisms that are generally recognized as safe (GRAS), such as B. subtilis and S. cerevisiae, have a higher potential for practical application pistachio industry. Siahmoshteh et al. (2017) demonstrated that both strains could decrease the mycelial growth in vitro, reducing the production of $\mathrm{AFB}_{1}, \mathrm{AFB}_{2}, \mathrm{AFG}_{1}$, and $\mathrm{AFG}_{2}$ during the first 3 days after inoculation.

\section{Conclusions}

The results of this study indicate that the occurrence levels of $\mathrm{AFB}_{1}$ in the Persian pistachio cultivars are a public health concern as $72 \%$ of the studies reported concentrations higher than the acceptable level per the Iranian National Standard for this product. The high incidence of AFTs in the Iranian pistachio is probably due to a lack of knowledge among the farmers, pistachio terminals, and the pistachio processing stages on the preventive 
measures with regard to toxigenic fungi contamination of foodstuffs. Therefore, further preventive actions and also ongoing monitoring can counter the potential risk of AFT in pistachios. Although several experimental techniques have been proposed for the reduction of the AFT content in pistachio nuts, the inoculation of GRAS microorganisms shows the most significant potential for future applications in the pistachio industry.

\section{References}

Abdallah, M.F., Ameye, M., De Saeger, S., Audenaert, K. and Haesaert, G., 2018. Biological control of mycotoxigenic fungi and their toxins: An update for the pre-harvest approach. In: Mycotoxins-impact and management strategies. IntechOpen. Patrick Berka Njobeh and Francois Stepman, London, UK, https://doi.org/10.5772/intechopen.76342

Abdallah, M.F., Audenaert, K., Lust, L., Landschoot, S., Bekaert, B., Haesaert, G., De Boevre, M. and De Saeger, S., 2020. Risk characterization and quantification of mycotoxins and their producing fungi in sugarcane juice: A neglected problem in a widely-consumed traditional beverage. Food Control 108: 106811. https://doi.org/10.1016/j.foodcont.2019.106811

Abdolshahi, A., Shabani, A.A., Mortazavi, S.A. and Marvdashti, L.M., 2018. Aflatoxin binding efficiency of Saccharomyces cerevisiae mannoprotein in contaminated pistachio nuts. Food Control 87: 17-21. https://doi.org/10.1016/j. foodcont.2017.12.008

Afshari, H., Talaie, A., Mohammadi Moghadam, M. and Panahi, B., 2009. Differences of elements in early splitting of pistachio nuts and the effect of phenolic compounds and gallic acid on rate. Journal of Horticulture Science 23: 10-17. [In Persian]

Afsharmanesh, H., Perez-Garcia, A., Zeriouh, H., Ahmadzadeh, M. and Romero, D., 2018. Aflatoxin degradation by Bacillus subtilis UTB1 is based on production of an oxidoreductase involved in bacilysin biosynthesis. Food Control 94: 48-55. https://doi. org/10.1016/j.foodcont.2018.03.002

Aghamohammadi, M., Hashemi, J., Kram, G.A. and Alizadeh, N., 2007. Enhanced synchronous spectrofluorimetric determination of aflatoxin B1 in pistachio samples using multivariate analysis. Analytica Chimica Acta 582: 288-294. https://doi.org/10.1016/j. aca.2006.09.014

Alshannaq, A. and Yu, J.-H., 2017. Occurrence, toxicity, and analysis of major mycotoxins in food. International Journal of Environmental Research and Public Health 14: 632. https://doi. org/10.3390/ijerph14.060632

Aydin, S. and Ulvi, M., 2019. Residue levels of pesticides in nuts and risk assessment for consumers. Quality Assurance and Safety of Crops \& Foods 11: 539-548. https://doi.org/10.3920/ QAS2018.1405

Bashiri, P., Hadad Khodaparast, M.H., Sedaghat, N., Tabatabaei Yazdi, F. and Nasiri Mohalati, M., 2013. The effects of solution ozone in water on aflatoxin reduction of O'hadi pistachio cultivar. Iranian Food Science and Technology Research Journal 9: 215-221. [In Persian]
Batrinou, A., Houhoula, D. and Papageorgiou, E., 2020. Rapid detection of mycotoxins on foods and beverages with enzyme linked immunosorbent assay. Quality Assurance and Safety of Crops \& Foods 12: 40-49. https://doi.org/10.15586/QAS2019.654.

Bensassi, F., Rhouma, A., Ghrab, M., Bacha, H. and Hajlaoui, M.R., 2010. Evaluation of cultivar susceptibility and storage periods towards aflatoxin B1 contamination on pistachio nuts. Mycotoxin Research 26: 199-203. https://doi.org/10.1007/ s12550-010-0054-7

Campagnollo, F.B., Ganev, K.C., Khaneghah, A.M., Portela, J.B., Cruz, A.G., Granato, D., Corassin, C.H., Oliveira, C.A.F. and Sant'Ana, A.S., 2016. The occurrence and effect of unit operations for dairy products processing on the fate of aflatoxin M1: A review. Food Control 68: 310-329. https://doi.org/10.1016/j. foodcont.2016.04.007

Chegini, S., Behbodi, K., Javan Nikkhah, M. and Farzaneh, M., 2013. Study of the effects of Trichoderma isolates on prevent of fungal growth of Aspergillus flavus and aflatoxin reduction on pistachio. Journal of Biological Control Pests Plant Diseases 2: 71-79. [In Persian]

Chen, R., Ma, F., Li, P.-W., Zhang, W., Ding, X.-X., Zhang, Q., Li, M., Wang, Y.-R. and Xu, B.-C., 2014. Effect of ozone on aflatoxins detoxification and nutritional quality of peanuts. Food Chemistry 146: 284-288. https://doi.org/10.1016/j. foodchem.2013.09.059

Cheraghali, A., Yazdanpanah, H., Doraki, N., Abouhossain, G., Hassibi, M., Ali-Abadi, S., Aliakbarpoor, M., Amirahmadi, M., Askarian, A. and Fallah, N., 2007. Incidence of aflatoxins in Iran pistachio nuts. Food and Chemical Toxicology 45: 812-816. https://doi.org/10.1016/j.fct.2006.10.026

Dargahi, R., Moradi, M., Fani, S.R. and Masoumi, H., 2014. Evaluation of aflatoxin $B_{1}$ in different parts of pistachio fruit and effects of processing stages. Journal of Food Hygiene 4: 21-31. [In Persian]

Dini, A., Khazaeli, P., Roohbakhsh, A., Madadlou, A., Pourenamdari, M., Setoodeh, L., Askarian, A., Doraki, N., Farrokhi, H. and Moradi, H., 2013. Aflatoxin contamination level in Iran's pistachio nut during the years 2009-2011. Food Control 30: 540-544. https://doi.org/10.1016/j.foodcont.2012.08.012

Ehrlich, K.C., Kobbeman, K., Montalbano, B.G. and Cotty, P.J., 2007. Aflatoxin-producing Aspergillus species from Thailand. International Journal of Food Microbiology 114: 153-159. https://doi.org/10.1016/j.ijfoodmicro.2006.08.007

European Commission, 2010. Amending regulation setting maximum levels, for certain contaminants in foodstuffs as regards aflatoxins. Official Journal of the European Union 1881- L50: 8-12.

FAO, 2016. FAOSTAT-Statistical Service, FAO, Rome.

Farzaneh, M., Shi, Z.-Q., Ghassempour, A., Sedaghat, N., Ahmadzadeh, M., Mirabolfathy, M. and Javan-Nikkhah, M., 2012. Aflatoxin B1 degradation by Bacillus subtilis UTBSP1 isolated from pistachio nuts of Iran. Food Control 23: 100-106. https://doi.org/10.1016/j.foodcont.2011.06.018

Georgiadou, M., Dimou, A. and Yanniotis, S., 2012. Aflatoxin contamination in pistachio nuts: A farm to storage study. Food Control 26: 580-586. https://doi.org/10.1016/j. foodcont.2012.02.014 
Haji Mohammadi, B., Ehrampoush, M.H., Hashemi, S., Khalatbari Limaki, S., Zare, F. and Taheri Soudejani, M., 2016. The effect of electron irradiation on aflatoxin B1 in pistachio production process inoculated with Aspergillus flavus. Journal of Toloo-eBehdasht 16: 1-8. [In Persian]

Heshmati, A., Zohrevand, T., Khaneghah, A.M., Mozaffari Nejad, A.S. and Sant'Ana, A.S., 2017. Co-occurrence of aflatoxins and ochratoxin A in dried fruits in Iran: Dietary exposure risk assessment. Food and Chemical Toxicology 106: 202-208. https://doi.org/10.1016/j.fct.2017.05.046

Hussein, H.S. and Brasel, J.M., 2001. Toxicity, metabolism, and impact of mycotoxins on humans and animals. Toxicology 167: 101-134. https://doi.org/10.1016/S0300-483X(01)00471-1

Ijabadeniyi, O., Mbedla, A. and Ajayeoba, T., 2020. Microbiological quality and antimicrobial efficacy of combined oregano essential oil and acetic acid on fresh lettuce. Italian Journal of Food Science 32(2): 399-409. https://doi.org/10.14674/IJFS-1566

ISIRI (Institute of Standard and Industrial Research of Iran), 2002. Maximum tolerated limits of mycotoxins in foods and feeds. National Standard No.5925. ISIRI, Karaj, Iran.

Khaneghah, A.M., Fakhri, Y., Gahruie, H.H., Niakousari, M. and Sant'Ana, A.S., 2019. Mycotoxins in cereal-based products during 24 years (1983-2017): A global systematic review. Trends in Food Science \& Technology 91: 95-105. https://doi. org/10.1016/j.tifs.2019.06.007

Khaneghah, A.M., Fakhri, Y., Raeisi, S., Armoon, B. and Sant'Ana, A.S., 2018. Prevalence and concentration of ochratoxin A, zearalenone, deoxynivalenol and total aflatoxin in cereal-based products: A systematic review and meta-analysis. Food and Chemical Toxicology 118: 830-848. https://doi. org/10.1016/j.fct.2018.06.037

Khorasani, S., Azizi, M.H., Barzegar, M., Hamidi-Esfahani, Z. and Kalbasi-Ashtari, A., 2017. Inhibitory effects of cinnamon, clove and celak extracts on growth of Aspergillus flavus and its aflatoxins after spraying on pistachio nuts before cold storage. Journal of Food Safety 37: e12383. https://doi.org/10.1111/jfs.12383

Kola, O., Hayoğlu, İ., Türkoğlu, H., Parıldı, E., Ak, B.E. and Akkaya, M.R., 2018. Physical and chemical properties of some pistachio varieties (Pistacia vera L.) and oils grown under irrigated and non-irrigated conditions in Turkey. Quality Assurance and Safety of Crops \& Foods 10: 383-388. https://doi. org/10.3920/QAS2017.1152

Krska, R. and Molinelli, A., 2009. Rapid test strips for analysis of mycotoxins in food and feed. Analytical and Bioanalytical Chemistry 393: 67-71. https://doi.org/10.1007/ s00216-008-2424-y

Kwaśniewska, K., Gadzała-Kopciuch, R. and Cendrowski, K., 2015. Analytical procedure for the determination of zearalenone in environmental and biological samples. Critical Reviews in Analytical Chemistry 45: 119-130. https://doi.org/10.1080/104 08347.2014.896731

Maragos, C. and Busman, M., 2010. Rapid and advanced tools for mycotoxin analysis: A review. Food Additives and Contaminants 27: 688-700. https://doi.org/10.1080/19440040903515934.

Mehrnezhad, M.R. and Panahi, B., 2005. The influence of hull cracking on aflatoxin contamination and insect infestation in pistachio nuts. Entomology and Phytopathology 73: 105-123. [In Persian]

Mohammadi Moghadam, M., Afshari, H., Mohammadi Goltape, E., Hokmabadi, H. and Rad, S., 2011. Investigation of the effects of testa in reducing growth of Aspergillus flavus fungi aflatoxin and production of aflatoxin $B_{1}$ in different cultivars of pistachio kernel. Journal of Horticulture Science 25: 73-81. [In Persian]

Mokhtarian, M., 2015. Thermodynamic study of a solar dryer equipped with air recycle and uses it to modeling of pistachio drying process by using genetic algorithm and artificial neural network approaches. PhD dissertation. Islamic Azad University, pp. 1-205. [In Persian]

Mokhtarian, M., Tavakolipour, H. and Ashtari, A.K., 2017. Effects of solar drying along with air recycling system on physicochemical and sensory properties of dehydrated pistachio nuts. LWT 75: 202-209. https://doi.org/10.1016/j.lwt.2016.08.056

Mokhtarian, M., Tavakolipour, H. and Kalbasi-Ashtari, A., 2016. Energy and exergy analysis in solar drying of pistachio with air recycling system. Drying Technology 34: 1484-1500. https:// doi.org/10.1080/07373937.2015.1129499

Mortazavi, A. and Tabatabai, F., 1998. Mycotoxins, pp. 1-206. [In Persian]

Mousavi Khaneghah, A., Fakhri, Y. and Sant'Ana, A.S., 2018. Impact of unit operations during processing of cereal-based products on the levels of deoxynivalenol, total aflatoxin, ochratoxin A, and zearalenone: A systematic review and meta-analysis. Food Chemistry 268: 611-624. https://doi.org/10.1016/j. foodchem.2018.06.072

Nabizadeh, S., Shariatifar, N., Shokoohi, E., Shoeibi, S., Gavahian, M., Fakhri, Y., Azari, A. and Khaneghah, A.M., 2018. Prevalence and probabilistic health risk assessment of aflatoxins B 1, B 2, G 1, and G 2 in Iranian edible oils. Environmental Science and Pollution Research 25: 35562-35570. https://doi. org/10.1007/s11356-018-3510-0

Ostadrahimi, A., Ashrafnejad, F., Kazemi, A., Sargheini, N., Mahdavi, R., Farshchian, M. and Mahluji, S., 2014. Aflatoxin in raw and salt-roasted nuts (pistachios, peanuts and walnuts) sold in markets of Tabriz, Iran. Jundishapur Journal of Microbiology 7: 1-4. https://doi.org/10.5812/jjm.8674

Pak-kish, Z. and Rahemi, M., 2005. The effect of gibberellic acid on reduced cracking of pistachio hull, aflatoxin, and quality of dried pistachio fruit. Journal of Science and Technology of Agriculture and Natural Resources 9: 69-78. [In Persian]

Panahirad, S., Zaare-Nahandi, F., Mohammadi, N., AlizadehSalteh, S. and Safaie, N., 2014. Effects of salicylic acid on Aspergillus flavus infection and aflatoxin B1 accumulation in pistachio (Pistacia vera L.) fruit. Journal of the Science of Food and Agriculture 94: 1758-1763. https://doi.org/10.1002/ jsfa. 6488

Pascale, M.N., 2009. Detection methods for mycotoxins in cereal grains and cereal products. Zbornik Matice srpske za prirodne nauke 117: 15-25. https://doi.org/10.2298/ZMSPN0917015P

Pereira, V., Fernandes, J. and Cunha, S., 2014. Mycotoxins in cereals and related foodstuffs: A review on occurrence and recent methods of analysis. Trends in Food Science \& Technology 36: 96-136. https://doi.org/10.1016/j.tifs.2014.01.005 
Pigłowski, M., 2019. Comparative analysis of notifications regarding mycotoxins in the Rapid Alert System for Food and Feed (RASFF). Quality Assurance and Safety of Crops \& Foods 11: 725-735. https://doi.org/10.3920/QAS2018.1398

Rahaie, S., Emam-Djomeh, Z., Razavi, S. and Mazaheri, M., 2010a. Immobilized Saccharomyces cerevisiae as a potential aflatoxin decontaminating agent in pistachio nuts. Brazilian Journal of Microbiology 41: 82-90. https://doi.org/10.1590/ S1517-83822010000100014

Rahaie, S., Razavi, S.H. and Emam Jomeh, Z., 2010b. The ability of Saccharomyces Cerevisiae strain in Aflatoxin reduction in Pistachio nuts. Journal of Food Science and Technology 7: 81-88. [In Persian]

Rahmani, J., Alipour, S., Miri, A., Fakhri, Y., Riahi, S.-M., Keramati, H., Moradi, M., Amanidaz, N., Pouya, R.H., Bahmani, Z. and Mousavi Khaneghah, A., 2018. The prevalence of aflatoxin M1 in milk of Middle East region: A systematic review, meta-analysis and probabilistic health risk assessment. Food and Chemical Toxicology 118: 653-666. https://doi. org/10.1016/j.fct.2018.06.016

RASFF, 2016. The Rapid Alert System for Food and Feed - Annual report. Available at: https://ec.europa.eu/food/safety/rasff_en (Accessed November 2017).

Rastegar, H., Shoeibi, S., Yazdanpanah, H., Amirahmadi, M., Khaneghah, A.M., Campagnollo, F.B. and Sant'Ana, A.S., 2017. Removal of aflatoxin $\mathrm{B} 1$ by roasting with lemon juice and/or citric acid in contaminated pistachio nuts. Food Control 71: 279284. https://doi.org/10.1016/j.foodcont.2016.06.045

Ros, E., 2010. Health benefits of nut consumption. Nutrients 2: 652682. https://doi.org/10.3390/nu2070652

Rossi, C.N., Takabayashi, C.R., Ono, M.A., Saito, G.H., Itano, E.N., Kawamura, O., Hirooka, E.Y. and Ono, E.Y.S., 2012. Immunoassay based on monoclonal antibody for aflatoxin detection in poultry feed. Food Chemistry 132: 2211-2216. https://doi.org/10.1016/j.foodchem.2011.12.067

Sakamoto, S., Putalun, W., Vimolmangkang, S., Phoolcharoen, W., Shoyama, Y., Tanaka, H. and Morimoto, S., 2018. Enzyme-linked immunosorbent assay for the quantitative/qualitative analysis of plant secondary metabolites. Journal of Natural Medicines 72: 32-42. https://doi.org/10.1007/s11418-017-1144-z

Serra, M.S., Pulles, M.B., Mayanquer, F.T., Vallejo, M.C., Rosero, M.I., Ortega, J.M. and Naranjo, L.N., 2018. Evaluation of the use of gamma radiation for reduction of aflatoxin B1 in corn (zea mays) used in the production of feed for broiler chickens. Journal of Agricultural Chemistry and Environment 7: 21. https://doi.org/10.4236/jacen.2018.71003

Shakeri, P. and Fazaeli, H., 2016. Microbial contamination and concentration of aflatoxin in pistachio by-product. Journal of Food Microbiology 3: 61-72. [In Persian]

Siahmoshteh, F., Siciliano, I., Banani, H., Hamidi-Esfahani, Z., Razzaghi-Abyaneh, M., Gullino, M.L. and Spadaro, D., 2017.
Efficacy of Bacillus subtilis and Bacillus amyloliquefaciens in the control of Aspergillus parasiticus growth and aflatoxins production on pistachio. International Journal of Food Microbiology 254: 47-53. https://doi.org/10.1016/j.ijfoodmicro.2017.05.011

Suzuki, T., Munakata, Y., Morita, K., Shinoda, T. and Ueda, H., 2007. Sensitive detection of estrogenic mycotoxin zearalenone by open sandwich immunoassay. Analytical Sciences 23: 65-70. https://doi.org/10.2116/analsci.23.65

Taghizadeh, S.F., Rezaee, R., Davarynejad, G., Asili, J., Nemati, S.H., Goumenou, M., Tsakiris, I., Tsatsakis, A.M., Shirani, K. and Karimi, G., 2018. Risk assessment of exposure to aflatoxin B1 and ochratoxin A through consumption of different Pistachio (Pistacia vera L.) cultivars collected from four geographical regions of Iran. Environmental Toxicology and Pharmacology 61: 61-66. https://doi.org/10.1016/j.etap.2018.05.010

Tavakolipour, H., Javanmard Dakheli, M. and Zirjani, L., 2010. The inhibitory effect of edible coating of pistachio kernel basis of whey protein concentrate and Shirazi thyme extract on the production of aflatoxin toxin. Journal of Innovation in Food Science and Technology 2: 53-63. [In Persian]

Tavakolipour, H., Javanmard, M. and Zirjany, L., 2012. Antiaflatoxigenic activity of pistachio kernel coated by whey protein based edible film incorporated with zataria multiflura essential oil. Journal of Food Science and Technology 36: 11-19. [In Persian]

Tavakolipour, H. and Mokhtarian, M., 2014. Estimation of equilibrium moisture content of pistachio powder through the ANN and GA approaches. International Journal of Food Engineering 10: 747-755. https://doi.org/10.1515/ijfe-2013-0022

Tavakolipour, H. and Mokhtarian, M., 2016. New approach to the calculation of pistachio powder hysteresis. International Agrophysics 30: 245-251. https://doi.org/10.1515/ intag-2015-0093

Tavakolipour, H., Mokhtarian, M. and Kalbasi-Ashtari, A., 2017. Lipid oxidation kinetics of pistachio powder during different storage conditions. Journal of Food Process Engineering 40: e12423. https://doi.org/10.1111/jfpe.12423

Turner, N.W., Bramhmbhatt, H., Szabo-Vezse, M., Poma, A., Coker, R. and Piletsky, S.A., 2015. Analytical methods for determination of mycotoxins: An update (2009-2014). Analytica Chimica Acta 901: 12-33. https://doi.org/10.1016/j. aca.2015.10.013

Yazdanpanah, H., Mohammadi, T., Abouhossain, G. and Cheraghali, A.M., 2005. Effect of roasting on degradation of aflatoxins in contaminated pistachio nuts. Food and Chemical Toxicology 43: 1135-1139. https://doi.org/10.1016/j. fct.2005.03.004

Zhang, L., Dou, X.-W., Zhang, C., Logrieco, A.F. and Yang, M.-H., 2018. A review of current methods for analysis of mycotoxins in herbal medicines. Toxins 10: 65. https://doi.org/10.3390/ toxins 10020065 